\title{
Status of the emission and transfer of pollutants in a medium-sized region
}

\author{
Dora E. Ledesma-Carrión ${ }^{1}\left[\right.$ ] Amós A. Pérez-Hernández ${ }^{2}$ - Lidia Hernández-Hernández ${ }^{1}$
}

Received: 22 October 2019 / Accepted: 5 March 2020 / Published online: 19 March 2020

(c) Springer Nature Switzerland AG 2020

\begin{abstract}
The objectives of this work are to analyze the relationships of the productive structure, private consumption and harmful emissions to living beings and the environment. To identify economic activities with the highest amount of pollutants and which social groups consume the most products associated with these emissions. To determine the polluting substances associated with these consumptions. There are no detailed studies of this nature on the chosen region. Input-output, social accounting and pollutant matrices can contribute to a better understanding of the causes for implementing public policies that mitigate these harmful emissions. Conventional methodologies are used as the method of location quotients and the Flegg approach. Some results show that the manufacture of products is based on nonmetallic minerals, textile, leather and paper industries. As well as pipeline transport is the industry that pollutes the most in the air, water and soil, respectively. The most abundant pollutants in the air are carbon dioxide and formaldehyde in water, lead and nickel and on the soil, arsenic. The last one is accompanied by cadmium and mercury in mining, vehicle assembly and pipeline wear processes. Households with higher incomes contribute to pollution through the consumption of machinery and equipment manufacturing products, petroleum and coal products, beverages and tobacco. For middle-income households, in addition to the previous ones, it impacts pipeline transportation. The last one is related to the damage in pipes by the transport of water, gas and gasoline. For the consumption of all households despite of its income, the food industry is the one that most impacts this category. This investigation is mainly based on the use of administrative records. It would be proactive to promote awareness policies for homes and businesses on the monitoring of sewer pipes and networks. The areas where these emissions were detected correspond to the most populated area in the region.
\end{abstract}

Keywords Regionalization · Pollutants · Transfer medium · Economic structure

List of symbols

A Matrix of technical coefficients

AFLQ Increased Flegg

$a_{i j} \quad$ Technical coefficient

$A^{m m} \quad$ Sub-matrix of technical coefficients of the region $m$

$A^{m n} \quad$ Sub-matrix of technical coefficients that reflect the exchanges from region $n$ to region $m$

C Pollutant matrix

CC Current accounting

$\begin{array}{ll}\mathrm{CH}_{2} & \text { Methylene } \\ \mathrm{CO}_{2} & \text { Carbon dioxide } \\ \mathrm{CyGEI} & \text { National emissions registry of carbon and } \\ & \text { greenhouse gases } \\ E & \text { Companies } \\ \vec{e} & \text { Sectorial emissions vector } \\ e_{i} & \text { Exports of goods and services } \\ \mathbf{G} & \text { Final demand matrix } \\ G & \text { Government } \\ H & \text { Household } \\ \mathbf{I} & \text { Identity matrix }\end{array}$

$\triangle$ Dora E. Ledesma-Carrión, dora.ledesma@inegi.org.mx; Amós A. Pérez-Hernández, amos.perez@inegi.org.mx; Lidia Hernández-Hernández, lidia.hernandezh@inegi.org.mx | ${ }^{1}$ Instituto Nacional de Estadística y Geografía, Av. Patriotismo 711, Col. San Juan Mixcoac,

Del. Benito Juárez, C.P. 03730, México CdMx., Mexico. ${ }^{2}$ Instituto Nacional de Estadística y Geografía, Av. Héroe de Nacozari Sur 2301 ,

Col. Fraccionamiento Jardines del Parque, C.P. 20276, Aguascalientes Ags., Mexico.

SN Applied Sciences (2020) 2:710 | https://doi.org/10.1007/s42452-020-2437-5 


$\begin{array}{ll}K & \text { Capital } \\ \mathrm{KC} & \text { Capital account } \\ L & \text { Labor } \\ \mathrm{LQ} & \text { Localized coefficients } \\ m_{i} & \text { Imports of commodity } i \\ M_{j}^{r} & \text { Regional imports } \\ \mathrm{NO}_{2} & \text { Nitrogen dioxide } \\ p_{i}^{\mathrm{r}} & \text { Proportion of regional supply of good } i \\ \mathrm{SF}_{4} & \text { Sulfur tetrafluoride } \\ T & \text { Transferences matrix } \\ T_{j}^{\mathrm{r}} & \text { Regional taxes } \\ u_{i} & \text { Total consumption by sector } j \text { of purchased } \\ & \text { inputs from others industries } \\ V & \text { Added value matrix } \\ V_{i} & \text { Total consumption of primary inputs } \\ & \text { (added value) in sector } j \\ V_{j}^{\mathrm{r}} & \text { Regional gross added value } \\ X & \text { Economic activities relations matrix } \\ x_{i} & \text { Total production of commodity } i \\ X_{j}^{\mathrm{r}} & \text { Regional production } \\ \vec{y} & \text { Final demand vector } \\ y_{i} & \text { Final demand of commodity } i \\ Z_{i} & \text { Total intermediate consumption of com- } \\ & \text { modity } i \\ Z_{i j} & \text { Quantity of commodity } i \text { consumed by sec- } \\ Z & \text { tor } j \\ Z \mathrm{ZRE} \mathrm{T}_{j} & \text { Demand of rest of the states and rest of world } \\ \lambda & \text { Total regional demand for intermediate } \\ \lambda & \text { goods } \\ & \text { Factor of relative size of the region } \\ & \end{array}$

\begin{tabular}{|c|c|}
\hline \multicolumn{2}{|c|}{ Abbreviations } \\
\hline COA & Annual Operation Certificate \\
\hline IOT & Input-output tableau \\
\hline IOTAgs13 & $\begin{array}{l}\text { Input-output tableau of Aguascalientes, } \\
\text { year } 2013\end{array}$ \\
\hline NAIC & $\begin{array}{l}\text { North America Industrial Classification } \\
\text { System }\end{array}$ \\
\hline RoW & Rest of world \\
\hline SAM & Social accounting matrix \\
\hline SAMAgs13 & $\begin{array}{l}\text { Social accounting matrix of Aguascalientes, } \\
\text { year } 2013\end{array}$ \\
\hline SLQ & Simple localization quotients \\
\hline CFC & Chlorofluorocarbons \\
\hline CILQ & Cross-industry location quotients \\
\hline CTADA & $\begin{array}{l}\text { Total cost of depletion and environmental } \\
\text { degradation }\end{array}$ \\
\hline ENIGH & $\begin{array}{l}\text { National household income and expendi- } \\
\text { ture survey }\end{array}$ \\
\hline FLQ & $\begin{array}{l}\text { Flegg's method of localization and } \\
\text { approach }\end{array}$ \\
\hline GCF & Gross capital formation \\
\hline
\end{tabular}

\begin{tabular}{|c|c|}
\hline GDP & Gross domestic product \\
\hline HFC & Hydrofluorocarbons \\
\hline INEGI & $\begin{array}{l}\text { National Institute of Statistic and } \\
\text { Geography }\end{array}$ \\
\hline RETC & Pollutant Release and Transfer Register \\
\hline LQ & $\begin{array}{l}\text { Semilogarithmic of Round localization } \\
\text { quotients }\end{array}$ \\
\hline SCILQ & $\begin{array}{l}\text { Symmetric cross-industry localization } \\
\text { quotients }\end{array}$ \\
\hline SCNM & System of national accounts of Mexico \\
\hline SEMARNAT & $\begin{array}{l}\text { Secretary of the Environment and Natural } \\
\text { Resources }\end{array}$ \\
\hline & Secretariat of Finance and Public Credit \\
\hline
\end{tabular}

1 Introduction

Throughout the last decades, there has been an interest in preserving the environment and natural resources. Mexico signs the Kyoto Protocol (1997) and ratifies it (2013) in order to reduce dioxide of carbon and equivalents $\left(\mathrm{CO}_{2}\right.$ -equivalent) gases emissions.

According to NOM-165-SEMARNAT-2013, the catalog of contaminating substances has been extended taking a count their transfer medium (air, water and soil) and economic class.

The sources of information related to this standard are mentioned below: Currently, the pollutant release and transfer register (RETC acronym in spanish) is published. It is a reporting instrument that covers information from 3,500 companies and its subsidiaries (which generate 16,287 records) in Mexico, and in the chosen study region, the State of Aguascalientes, 48 companies and 183 records. The database is located statewide and by economic activity according to the code of North America Industrial Classification System (NAICS). It is not a sample itself, but it contains enough information to incorporate it into methodologies that involve input-output tableau (IOT) and social accounting matrix (SAM). For the user who would like to analyze only the $\mathrm{CO}_{2}$-equivalent emissions $\left(\mathrm{CO}_{2}, \mathrm{~N}_{20}, \mathrm{CH}_{2}, \mathrm{HFCs}, \mathrm{CFCs}\right.$ and $\mathrm{SF}_{4}[1-3]$, it commonly uses the conversion of the Intergovernmental Panel on Climate Change based on the National Emissions Registry of carbon and greenhouse gases (CyGEI in spanish).The enterprises are considered as obligated subjects to report its direct and indirect emissions of greenhouse gases or compounds of all its facilities and must not exceed 25,000 tons of $\mathrm{CO}_{2}$-equivalent in the sectors of energy, industry, transport, agriculture, waste, commerce and services. The RETC is built from the Annual Operation Certificate (COA in spanish), a management tool created by the Ministry of Environment and Natural Resources (SEMARNAT). The 
COA is applied to all companies and is strictly supervised since 2014.

Some of the most important sectors in the increase in emissions in recent years in Aguascalientes are the manufacture of products based on nonmetallic minerals in air, the manufacture of textile inputs and textile finishing in water and the transport sector by pipelines on the soil. This supposes diffuse emission sources that are not regulated by some type of treatment or penalty according to pollutant substance and their mean of transfer. On the other hand, it is necessary to know the following definition to associate prices with contaminants. During the production process, environmental costs are generated derived from the depletion of natural resources and the degradation of the environment. The CTADAs reflect the expenses that society would have to incur to prevent or remedy the decrease and loss of natural resources, as well as the deterioration of the environment. By society, it include industries, companies, business, consumers (public and private) and government. The government subsidizes through rescue or remediation programs. Industries, companies and business pass exhaustion and remediation costs on to the final consumer. Society would have to pay, to remedy, restore or prevent the depletion and degradation of the environment.

For the year 2013, the CTADA is equivalent to $5.7791312 \%$ of the gross domestic product.

The mitigation goals are reducing CyGEI $30 \%$ at 2030 and $50 \%$ at 2050 , respectively, to the baseline and those issued in 2000; therefore, it is important to analyze the relationships between these emissions and the economic structure of the region. The appropriate analytical framework is the regional input-output Tableau (IOTAgs13) extended to regional social accounting matrix (SAMAgs13). The CTADA each year are published by the National Institute of Statistics and Geography (INEGI) in an aggregate manner.

On the other hand, regarding the methodological concepts, there are the following important aspects. When the IOT is built, interactions between economic activities are through merchandise flows (in terms of money). These flows have a conventional direction and meaning ranging from the demanding sectors (buyers) to the supplier sectors (sellers), that is, from the element in column $\mathrm{j}$ to the element in row $\mathrm{i}$ in a matrix arrangement. Then, the sum of the elements in the row represents the production of that economic activity taking into account inputs. The inputs are produced by other economic activities and/or by the same activity. Consequently, the sum of each row must equal the sum of its corresponding column. This is called balance sheet and is a basic principle for the construction of IOT and SAM. For the reader interested in deepening you can consult, for example, the works of Graham et al. [4] and Defourny and Thorbecke [5], where the convention of the flows and the mathematical handling for the basic decomposition in sub-matrices with economic sense are explained.
Finally, the objectives, goals and indicators of sustainable development were taken into account. In particular, one of the objectives was of relevance to develop this work. The ninth goal of sustainable development is to build resilient infrastructure, promote inclusive and sustainable industrialization and foster innovation (ONU).

Goal 9.2.1 Added value of the manufacturing sector in proportion to GDP and GDP per capita.

Goal 9.4.1 $\mathrm{CO}_{2}$ emissions per unit of added value.

Indicators such as the number of tons per capita of $\mathrm{CO}_{2}$ and the number of tons of $\mathrm{CO}_{2}$ emitted per monetary unit produced are relevant in order to quantify and track the objectives and, where appropriate, manage and implement corrective measures to meet them. In practice, the calculation of these indicators is not direct. It is necessary to have socioeconomic historical data and information on the processes carried out by companies. Subsequently, the costs of prevention, remediation or resilience are transferred to the population through the consumption of goods and services. The relationship between production processes and indicators is achieved using IOT and their extension to SAM. The SAM establishes the flows (in monetary terms) between factors, agents, economic activities and other variables called exogenous such as imports, exports, capital accounts and transfers to/from abroad. To achieve this, it is necessary to have abundant information provided by different sources and to be able to couple them using different methodologies.

A point to take into account is the fact that the indicators and specific goals regarding other pollutants that are emitted in the production processes are not established in the sustainable development goals (SDGs). For this reason, in this work, some other pollutants are considered in addition to $\mathrm{CO}_{2}$ emissions to obtain a reference on the status of emissions that are harmful to the environment and living things.

In order to transfer the technological costs of prevention, resilience or remediation to consumers, it is necessary to consult projects financed by the government and/or companies whose data are available to the public. This information links the pollutant substance(s) with the means of transfer and the cost of remediation, prevention or resilience according to the technology used. This cost is a function of time, surface, chemical, topographic and geographical characteristics of the place, as well as the source of the pollutant. Here lies the importance of the databases of RETC, CTADA and remediation projects. With all this information, the range of remediation costs per polluting substance is obtained and subsequently associated with the economic activities of the region.

The procedure to follow in great steps is:

1. From the national IOT and government data obtain the regional OIT.

2. Extend the regional OIT to a regional SAM. 
3. To adjust the regional SAM ensuring that total revenues equal total expenses to avoid inconsistencies. That is, the matrix must be balanced.

4. To make the aggregation at the subsector level of the pollutant and SAM matrices whose intermediate step is to obtain the matrices of Figs. 1 and 2.

5. To calculate the tons of pollutants per produced monetary unit.

6. To obtain tons per capita per pollutant by economic subsector per decile of household income.

In Sect. 2, a bibliographic review of the advances in this matter is made, and in Sect. 3, the methodology followed is presented. Summary results appear in Sect. 4. The analysis of results and discussion appears in Sect. 5. Finally, Sect. 6 presents the conclusions.

\section{Brief state of the art}

There are several studies at the state level that use the methodology of localized coefficients (LQ) applied to IOT. This methodology has been preponderantly applied in Mexico to regionalize IOT and SAM; examples of them are studies on labor and gender equity and dividing the country into four large regions [6]. For Mexico City and the metropolitan area, the basic multiplies are studied to identify the key sectors and the most important intersectoral flows [7]. Ayala-Gaytán et al. [8] calculate the financial impact due to replanting corn in Sinaloa State, using government resources, after a frost caused by climate change. Econometric techniques, SCNM and IOT data are applied to generate the input data for their proposed general equilibrium model. Central Bank of Mexico in 2017 released its regional study on the automotive sector based on the IOT-2012 published by INEGI [9]. For Guanajuato State, the availability of water has been studied [10], and for Nuevo Leon State, it analyzed the effect of economic policies on the well-being and social programs of the region [3, 11]. Although there are different methodologies for regionalizing an IOT, most authors recommend Flegg's method of localization and approach (FLQ), since there is no sufficient and conclusive information to use the other methods [1, 12]. Flegg and Tohmo [13] compare matrices constructed with complete local information and those approximated by the localized quota method, concluding that the FLQ is the most convenient method.

Therefore, in this paper the Flegg approach (FLQ) for the estimation of regional IOTs will be applied. To extend IOTAgs 13 to SAMAgs 13 a hybrid method was used following the suggestions of Martana et al. [14]. There is no information about prices, so costs will be used assuming zero benefits. These costs are the lowest denominated "weak costs" due to the difficulty to calculate them given the information available. To calculate the costs of emissions [15], considers them a negative externality. It was not necessary to do this here since the CTADA [16] data are available, which are based on different records [17]. The advantage of the latter is that it is calculated within an economic conceptual framework according to the System of National Accounts (SCNM) and is in terms of the gross domestic product. The CTADA are calculated according to the following items: (a) pollutant emissions into the atmosphere by mobile sources, (b) air pollutant emissions from fixed sources, (c) air emissions generated by area sources, (d) discharges of untreated wastewater, (e) groundwater depletion, (f) changes in land uses, (g) soil degradation, (h) depletion of hydrocarbons, (i) degradation by urban solid waste and (j) depletion of forest resources. Only CTADA data referring to fixed sources (a), areas (b), groundwater (e), solids (g) and reports on remediation costs published by mining companies will be used here. These calculations are based on historical data and administrative records, with which flows and standardized models are made, so when referring them in terms of GDP, it is an ad hoc association, since they are not following the production process. For this reason, prices to the buyer and zero or constant benefits of producer are used, since the cost of contaminants is transferred to final consumers [16]. To calculate elasticities, there are different methods. Livas-García [18] calculates elasticities for his model based on historical data from 1970 to 2010 . Functional forms of production in the energy industry are calculated. The structural analysis based on the IOT allows him to make observations on aspects of sustainable development linked to energy consumption. Here, the arc elasticity method was used [19]. No regionalized studies have been done by economic subsector for pollutant and transmission so far for the case of Mexico, only with CyGEI data, so this work creates an antecedent to extend this analysis.

Yue et al. [20] report that (in China) coal consumption is the main environmental impact in the paper production (1000 kg paper: $1415.39 \mathrm{~kg} \mathrm{CO}_{2}$ ) and volatile organic compounds in the printing services. If the tons per capita of the coal consumed were calculated, each person would have two packages of 500 letter-size sheets per year consuming 1 ton of $\mathrm{CO}_{2}$. It is clear that the process is much more complex and involves the use and emission of more substances. When applying the SAM methodology, the different inputs in the production processes are taken into account, giving another assessment from the point of view of the final consumer through intermediate consumption, agents and productive factors, and not only the quantification of the life cycle analysis and carbon footprint (water, energy, garbage, etc.). As the authors expressed, this triggers alerts in these activities by increasing water quality indicators: wastewater discharges, ammonia emission (NH3-N) and chemical oxygen demand. Quantifying emissions, their diffusion, treating of water and relating them to water quality provide planning elements 
for the SDGs. Worldwide it is known that agriculture is the main consumer of water followed by industry and households [21]. An aspect that emerge from this work to quantify is well-being. And a robust methodology that can integrate this aspect is multiple regression [22] and the decomposition of Leontief multipliers into a SAM [23]. Using input-output tableau and remediation costs information for groundwater [24], report to the services sector as the one that most impacts the environment, followed by agriculture and manufactures, for Malaysia. This is true for direct, indirect, induced and total impacts. The fifth place is taken together by the crude oil and natural gas, metal oe mining, stone clay and sand quarrying, and other mining and quarrying sectors. These activities for Aguascalientes State occupy the first two places. Bhalla et al. [25] also establish that the services sector is the one that most impacts the environment and is the one that most contributes to GDP for Malaysia. In order to make this evaluation, the authors develop a dynamic general equilibrium model using accounting multipliers as an input, based on an IOT. Therefore, the main economic indicator related to the impact on the environment is GDP. Studies on $\mathrm{CO}_{2}$ emissions due to international exchange use multiregional IOTs [26]. These show how much of these emissions are domestic or foreign.

\section{Methodology}

Based on the IOT, it is regionalized for Aguascalientes State applying the FLQ method. It is subsequently extended to a SAMAgs 13 using survey information and government reports. In addition, the matrix of pollutants in air, water and soil (MCAgs-13) was obtained. It is necessary to adapt the matrices at the subsector level since the information is published at different levels of disaggregation according to the source of information. The main ideas to regionalize an IOT are by supply-demand balance and by LQ. For Aguascalientes, there is little information that can be adapted so that the limits of this work were established. There is no information on imports from other states or abroad, the value added and/or gross value of production by NAICS subsectors. There is information about wage and salaries, occupied people, people, investment, social programs of government, etc. On the other hand, to break down private consumption in SAMAgs 13, the calculated weighted and disaggregated distribution of taxes per income decil was used, generated from the data published by the Secretariat of Finance and Public Credit (SHCP) for 2012 [27]. This distribution is based on the National Household Income and Expenditure Survey (ENIGH in spanish) for the year 2012 [16]). The total fiscal collection is applied, while the aggregate fiscal collection is not considered because it excludes the first two income deciles (due to the calculation of the aggregate load in which the individual charges are weighted with the value of the collection of each tax. Note: The lower deciles do not pay taxes except value added tax). The SHCP publishes what it collects from each tax in terms of distribution by income decile. To take into account all the diciles of income, the contribution of each tax was considered, calculating a total collection distribution per decil. The costs associated with degradation are related to air pollution and the degradation and contamination of soil and water. Between 2003 and 2012, the CTADA grew 51\%, from 652.67 thousand to 985.06 billion Mexican pesos (Mx\$). However, in proportional terms to the national gross domestic product (GDP), they were reduced from 8.5 to $6.3 \%$. On the other hand, the exhaustion costs were $1.7 \%$, of which hydrocarbons represented the highest percentage (1.4\% of GDP), with the remaining $0.3 \%$ distributed among the other components. The calculation of the CTADA for the region started from the national value as a percentage of the GDP (INEGI 2012 [16]). This percentage is distributed between some groups of economic sectors. As a result, the costs were distributed by branch of economic activity according to the proportion established by air pollution, depletion and degradation. Thus, the cost was obtained by branch of economic activity. For each branch of economic activity, pollutants were grouped into air, water and soil; thus weights were obtained per pollutant per branch of economic activity. In order to regionalize the costs, taking into account the weights per pollutant (\% CTADA/ton), it is typified with the own pollutants of Aguascalientes by branch of economic activity through transmission medium (air, water and soil). This was done for the years 2012 and 2013 to obtain the arc elasticities $[28,29]$. It is scaled to the SCNM through tons/Mx\$ of pollutants by branch of economic activity. This step should be done since the costs and tons of pollutants are based on records provided by companies. Since the RETC is in different units (grams, kilograms and tons), they are converted into tons (Tons).

\subsection{Estimation of the IOTAgs13}

There is abundant bibliography on the method of LQ, some references that can be consulted are given $[7,9,12$, $29,30]$, and the main ideas are outlined. Initially, a national matrix of technical coefficients is used together with an adjustment procedure that captures some of the characteristics of the regional economy, since there is no matrix of specific coefficients for the region. Starting from the IOT at national level and considering its structure (Table 1), it is proceeded to regionalize it taking into account the available information. The variables corresponding to the region will be denoted with the " $r$ " badge.

The formal structure of the IOT accounts can better be expressed by means of symbols. The essential elements are defined as follows: 


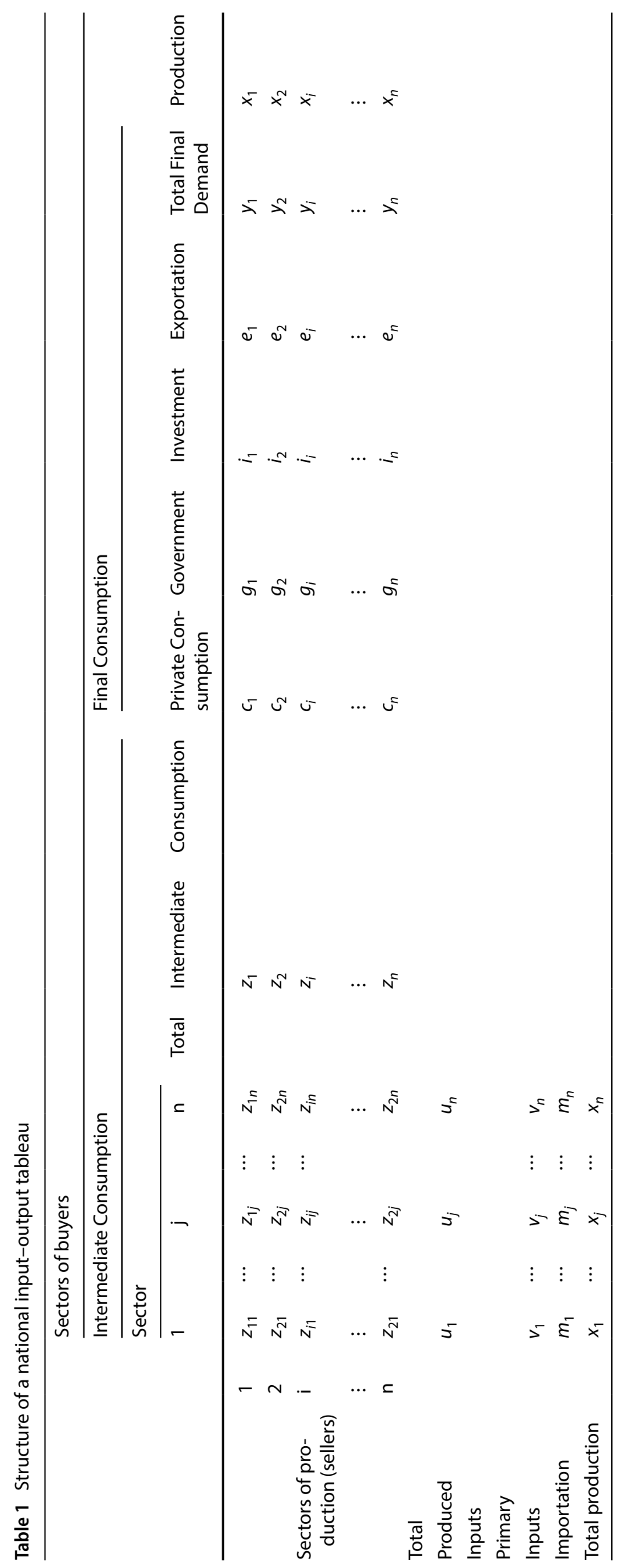




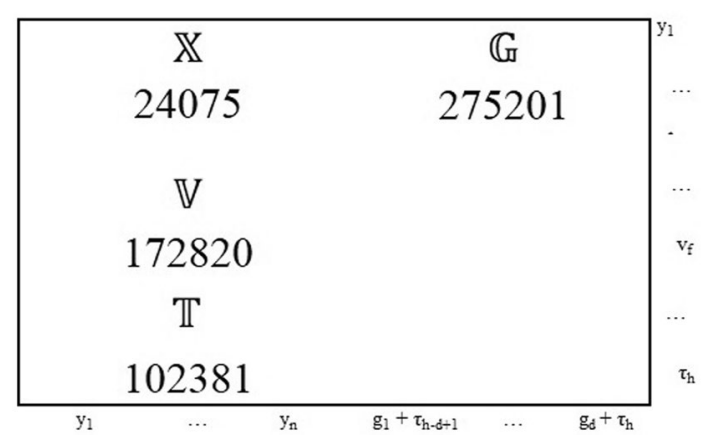

Fig. 1 Added social accounting matrix for State of Aguascalientes, year 2013. SAMAgs13. Matrices: $\mathbb{X}$ is economic activities, $\mathbb{G}$ final demand, $\mathbb{V}$ added value, $\mathbb{T}$ capital account and adjusted current account

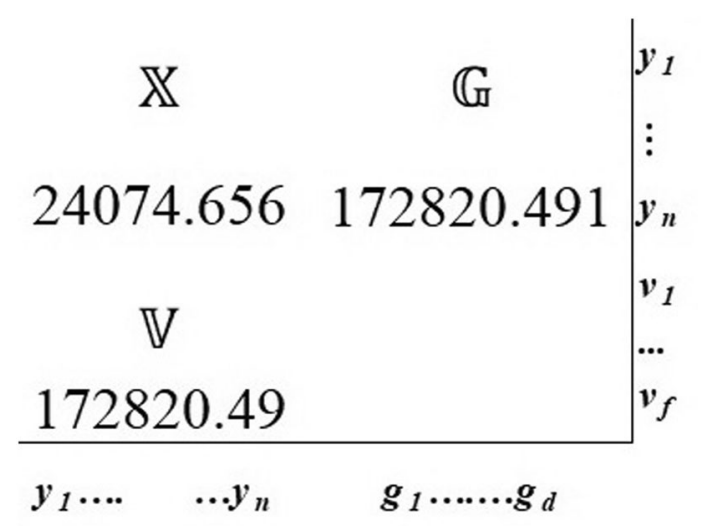

Fig. 2 Added social accounting matrix for State of Aguascalientes, year 2013. SAMAgs13. Matrices: $\mathbb{X}$ is economic activities, $\mathbb{G}$ adjusted final demand, $\mathbb{V}$ added value

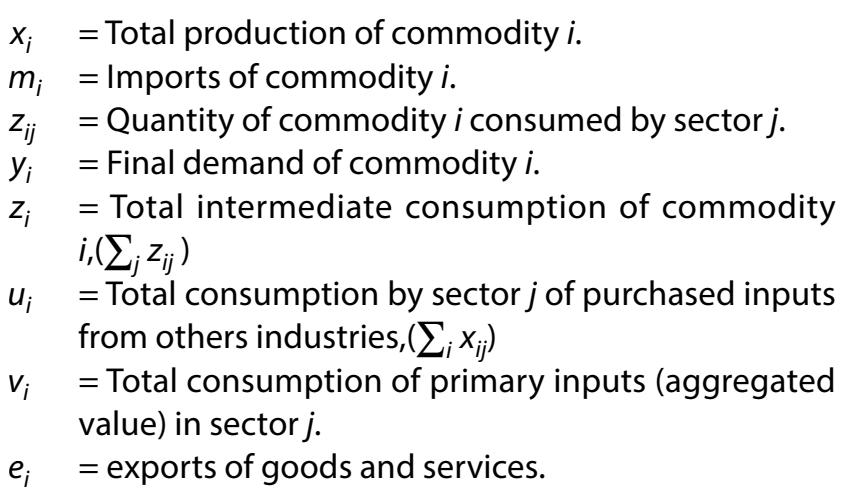

\subsection{Complete regional information}

Each variable of Table 1 is denoted for the region by "r." As well as $A$, the matrix that represents the contributions of the companies of the region to the production in that region which is denoted as $A^{r r}$, where $a_{i j}^{r r}$ is the quantity of inputs from sector $i$ to the production of sector $j$ in $r$. To obtain them, modifications are made through the use of estimated regional offer percentages, one for each subsector in the regional economy, designed to show the perception of the total required results of each subsector that could be expected to originate within the region. A simple way to estimate these percentages, using data that can often be obtained at a regional level, requires knowledge of (1) the total regional production of each sector $i, x_{i}^{r}$; (2) the product exports of each sector $i$ of the region $r, e_{i}^{r}$ and (3) imports of goods $i$ in the region $r, m_{i}^{r}$. Then, an expression can be formed for the proportion of the total quantity of good $i$ available in region $r$ that occurred in $r$ (the proportion of regional supply of good $i$ ). We denote this by $p_{i}^{r}$ where

$p_{i}^{r}=\frac{x_{i}^{r}-e_{i}^{r}}{x_{i}^{r}-e_{i}^{r}+m_{i}^{r}}$

The numerator is the quantity produced locally and available for sale in $r$. The denominator is the total amount available, whether locally produced or imported. Then for all $i$, the vector pr is built.

$A^{r r}=p^{r} A$

When information on imports is unknown, whether from other states or abroad, pr is estimated. When the national matrix is used to regionalize in a single region, the consistency of the partition must be taken care of, generating four zones in the matrix. Let be $z_{i j}^{r r}$ the flow of goods from sector $i$ in $r$ to sector $j$ in $r . Z^{r r}=z_{i j}^{r r}$ a matrix of $\mathrm{nxn}, x_{r}$ a vector $\mathrm{nx} 1$. Then,

$a_{i j}^{r r}=\frac{z_{i j}^{r r}}{x_{j}^{r}}$

So the coefficient matrix of the region is

$A^{r r} x^{r}=z^{r r}$

$x^{r}=\left(I-A^{r r}\right) y^{r}$

When dividing the national matrix in a study region $(r)$ and the rest (s),

$Z=\left[\begin{array}{ll}Z^{r r} & Z^{r s} \\ Z^{s r} & Z^{s s}\end{array}\right]$

By following the consistency of the partition, the corresponding coefficients are obtained

$a_{i j}^{s s}=\frac{z_{i j}^{s s}}{x_{j}^{s}}$

Interregionals where the denominator is the gross production of sectors in the receiving region. 


$$
\begin{aligned}
& a_{i j}^{r s}=\frac{Z_{i j}^{r s}}{X_{j}^{s}} \\
& a_{i j}^{s r}=\frac{Z_{i j}^{s r}}{X_{j}^{s}} \\
& A=\left[\begin{array}{ll}
A^{r r} & A^{r s} \\
A^{s r} & A^{s s}
\end{array}\right] ; x=\left[\begin{array}{l}
x^{r} \\
X^{s}
\end{array}\right] ; y=\left[\begin{array}{l}
y^{r} \\
y^{s}
\end{array}\right] ; l=\left[\begin{array}{ll}
I^{r r} & 0^{r s} \\
0^{s r} & 1^{s s}
\end{array}\right]
\end{aligned}
$$

Analogously as in (4):

$$
x^{s}=\left[\left(A^{s r}\right)^{-1}\left(I^{s s}-A^{s s}\right)-\left(I^{r r}-A^{r r}\right)^{-1} A^{r s}\right]^{-1}\left[\left(I^{r r}-A^{r r}\right)^{-1} y^{r}+\left(A^{s r}\right)^{-1} y^{s}\right]
$$

$x^{r}=\left[\left(A^{r s}\right)^{-1}\left(I^{r r}-A^{r r}\right)-\left(I^{s s}-A^{s s}\right)^{-1} A^{s r}\right]^{-1}\left[\left(I^{s s}-A^{s s}\right)^{-1} y^{s}+\left(A^{r s}\right)^{-1} y^{r}\right]$

\subsection{Incomplete regional information.}

Unless all the regional information was available, the previous system could be solved, but since this is not the case, it is necessary to make approximations, assumptions and apply hybrid methods. To obtain the regional technical coefficients, $a_{i j}^{r}$, from the national IOT the localization quotients (LQ) are used, some of them are the simple localization (SLQ), cross-industry location (CILQ), semilogarithmic of round (RLQ), symmetric cross-industry (SCILQ), Flegg (FLQ) and increased Flegg (AFLQ). Given the scarcity of data at the regional level, the FLQ [9] is chosen, which is the most used because it is the most consistent [13]. This method considers the relative size of the productive sectors, the size of the region considered and corrects for a bias associated with the sectoral aggregation procedures. This method assumes that the techniques of national and regional production are equal. The initial assumption is that the regional technical coefficients $\left(a_{i j}^{r}\right)$ are in principle equal to the national coefficients $\left(a_{i j}\right)$, so the consumption or demand of intermediate goods in sector $j$ in region $r$ is:

$Z_{j}^{r}=\sum_{i=1}^{n} a_{i j} X_{j}^{r}$

where $Z_{j}^{r}$ is the regional intermediate consumption of sector $j$ and $X_{j}^{r}$ is the gross regional production of sector $j$. When the $L Q_{i}$ is equal to 1 , it means that both the region and the national level have the same degree of specialization in that activity. If $\mathrm{LQ}_{i}>1$ indicates that the region has a greater productive concentration in activities i compared to the national average. Several steps are required to calculate the FLQ coefficients.

First, the SQLs are obtained:
$\mathrm{SLQ}_{i}=\frac{\frac{\mathrm{GDP}_{i}^{r}}{\mathrm{GDP}^{r}}}{\frac{\mathrm{GDP}_{i}}{\mathrm{GDP}}}$

Then, the CILQs are calculated:

$\mathrm{CILQ}_{i j}=\frac{\mathrm{SLQ}_{i}}{\mathrm{SLQ}_{j}}$

Next, the adjustment factor, $\lambda$, which weights the relative size of the region,

$\lambda=\left[\log _{2}\left(1+\frac{\mathrm{GDP}^{r}}{\mathrm{GDP}}\right)\right]^{\delta}$

where $0<\lambda<1 \mathrm{y} \delta=0.25$ [9]. This value of the parameter $\delta$ is the one that best approximates the regional matrices obtained with complete data observed and those estimated.

Subsequently, the FLQ are deduced, where

$\mathrm{FLQ}_{i j}=\mathrm{CILQ}_{i j} \times \lambda$

Finally, the following conditions are met:

$a_{i j}^{r}=\left\{\begin{array}{cl}a_{i j}, & \text { if } \mathrm{FLQ}_{i j} \geq 1 \\ a_{i j} \times \mathrm{FLQ}_{i j}, & \text { if } \mathrm{FLQ}_{i j}<1\end{array}\right.$

To build the regional IOT, it is necessary to know the national IOT, the national and regional GDP disaggregated to the level of the study, the components of the final demand, added value, imports, taxes, remunerations and gross operating surplus of the region. In this work, the disaggregation is at the subsector level of NAICS activity. There is no information on regional imports from other states and/or abroad. In the case of exports, there is information at the regional level. To construct the regional matrix of consumption of intermediate goods $Z^{r}$, the components of final demand, taxes, gross operating surplus and regional remunerations, for which there is no disaggregated information, rational estimates will be made based on the national distribution of value added and the final demand. Let be $Z_{i j}^{r}$ the intermediate consumption of regional origin of sector $j$ coming from sector $i$,

$Z_{i j}^{r}=a_{i j}^{r} \times X_{j}^{r}$

By definition

$X_{j}^{r}=V_{j}^{r}+Z T_{j}^{r}+M_{j}^{r}+T_{j}^{r}$

$V_{j}^{r}$ is the regional gross added value, $\mathrm{ZT}_{j}^{r}$ total regional demand for intermediate goods, $M_{j}^{r}$ regional imports and $T_{j}^{r}$ regional taxes. They will be estimated by distributing with respect to the final demand. It will be assumed that 
the tax rate and the average propensity to import are analogous at both the regional and national levels.

$$
\begin{aligned}
& X_{j}^{r}=V_{j}^{r}+\left(\sum_{i=1}^{n} a_{i j} X_{j}^{r}\right)+m_{j} X_{j}^{r}+t_{j} X_{j}^{r} \\
& X_{j}^{r}=V_{j}^{r}+\left(\sum_{i=1}^{n} a_{i j} X_{j}^{r}\right)+m_{j}^{r} X_{j}^{r}+t_{j}^{r} X_{j}^{r}
\end{aligned}
$$

For sector $j$,

$$
\begin{aligned}
& X_{j}^{r}\left(1-\left(\sum_{i=1}^{n} a_{i j}\right)-m_{j}^{r}-t_{j}^{r}\right)=V_{j}^{r} \\
& X_{j}^{r}=\frac{V_{j}^{r}}{1-\left(\sum_{i=1}^{n} a_{i j}\right)-m_{j}^{r}-t_{j}^{r}}
\end{aligned}
$$

So it is possible to estimate $Z_{j}^{r}$, the consumption of each sector $j$ of the different sectors supplying inputs. Then, the total intermediate consumption of sector $j$ of regional origin is

$Z_{j}^{r}=\sum_{i=1}^{n} Z_{i j}^{r}$

Each sector $j$ is consuming intermediate goods (unadjusted by Flegg) of

$Z T_{j}^{r}=\sum_{i=1}^{n} a_{i j} X_{j}^{r}$

The difference between what the region should consume if it maintained national production techniques less what actually consumes (adjusted) the total intermediate consumption of sector $j$ from the rest of the states $\left(Z R E_{j}\right)$ is

$\mathrm{ZRE}_{j}=Z T_{j}^{r}-Z_{j}^{r}$

This is calculated only with the interregional part, that is, with the $a_{i j}^{r r}$ coefficients. To estimate private and government consumption, the population distribution of the region and the percentage of participation of the region with respect to the national one are used. Investment equals gross fixed capital formation and stock variation. This is obtained by multiplying the value of national investment by the share of regional GDP in the national total. In the case of regional remuneration, regional participation is taken in relation to the national one; taxes on production are obtained by multiplying the income tax by the sectoral participation of the remunerations in the region; and the gross surplus of operation, which is the payment to capital, is obtained as a residual between the regional gross value added and the rest of its components; this is called completes and does not imply that it is a good approximation to the real values that only give congruence and consistency between national and regional economic structures. Private consumption is broken down into deciles of expenditure using the distribution of taxes collected [27] by households first and then by persons. To analyze the polluting substances by economic subsector, the standard procedure was followed, using instead of a pollutant vector, the pollutant matrix by mean of transfer. This matrix was transformed into one of coefficients of emission and transfer by subsector, normalizing the values with respect to the gross value of production in units of tons/millions of mexican pesos [tons/MMx\$]. The value of the pollutant due to sector $i$ is given by the domestic product between the vector of emissions by subsector NAICS and the production of subsector $i$. Generalizing: Let $C$ be a diagonal matrix. On the diagonal are the values of the polluting emissions by economic subsector. The vectors are exchanged whether the pollutant emissions are transferred by air, water or soil. Introducing this matrix to the Leontief model,

$$
\vec{e}=C(I-A)^{-1} \vec{y}
$$

$\vec{e} \quad$ Sectoral emissions vector

$\vec{y} \quad$ Final demand vector,

I Identity matrix,

A Matrix of technical coefficients,

C Pollutant matrix

The components of the final demand are private consumption, government consumption, gross capital formation, stock variation and exports. Subsequently, it is broken down by pollutant by subsector by transfer mean.

\subsection{Making of the SAMAgs13.}

Extending the IOTAgs 13 to SAMAgs13 [31], the following aggregate structure was established according to publicly available information. There is abundant bibliography on the hybrid methods, some references that can be consulted are given [14, 32, 33], and the main ideas are outlined.

Two available production factors: work ( $\mathrm{L}$ ) and capital $(\mathrm{K})$ are considered into matrix $\mathbb{V}$. This information is obtained from the IOTAgs 13. Institutions: Household $(H)$, companies $(\mathrm{E})$ and government $(\mathrm{G})$ are considered into matrix $\mathbb{G}$. Economic activities $(\mathbb{X})$ are broken down into 32 subsectors of economic activity. Capital accounts include the change in inventories in gross capital formation (KC), 
net indirect taxes, data obtained from the IOTAgs 13 and rest of the world (RoW). They include other states of the Republic and abroad. The intermediate demand, wages, salaries, contributions, gross surplus of operation, taxes on products, taxes on production and subsidies are obtained from the IOTAgs13. The final demand including private consumption (PC), government consumption, gross capital formation, stock variation, exports and statistical discrepancy are included into $\mathbb{G}$. Rest of the world includes the current account and the capital account, incoming and outgoing flows. Exports and imports are obtained from the IOTAgs 13.

$\mathrm{KC}$ and RoW are considered into matrix $\mathbb{T}$.

The receipt labor income from RoW, receipt capital income from RoW, paid labor income to RoW and paid capital income to RoW, from SAMAgs13, all of them were estimated using the data from the supply-use tables for the base year 2013. Local government reports and balancing items are used.

Export, import and net indirect taxes (net export) are included into $\mathbb{G}$. See Fig. 2.

\section{Results}

Analyzing the pollutant matrix, it is found that the main substances present in the three media, air, water and soil, are arsenic, cadmium, chromium, mercury, lead and nickel. Those found only in air are carbon dioxide, benzene, formaldehyde, phenol, chlorodifluoromethane (HCFC-22), acetaldehyde, furans, dioxins, methane and nitrous oxide. Cyanide is found in water and soil. The maximum pollutant emitted in tons is carbon dioxide followed by formaldehyde. In the case of arsenic it is mainly found in the soil, while chromium, mercury and lead are in the air (without taking into account carbon dioxide and formaldehyde). In the case of water, the most polluting is cyanide. When introducing the MCAgs-13 in the SAMAgs-13, the subsectors that contribute to air, water and soil pollution are obtained for private consumption, see Fig. 3 and Table 2 . Figure 3 shows the percentage contribution by means of substance transfer (the most representative). Table 2 shows the contribution by subsector to emissions to the three media. Table 2 is linked with Tables 3, 4 and 5 to obtain the fine breakdown of Fig. 3. Note: The tables only show the main sectors by question of space. For private consumption, the contributions for pollutants are shown in Tables 3, 4 and 5. As shown in Table 3, carbon dioxide is the one with the greatest presence in terms of mass [in tons], not the most toxic. The subsectors associated with the emission and transfer of pollutants appear in Tables 3 , 4,5 , highlighting the 327-manufacture of products based on nonmetallic minerals, 313-manufactures of textiles and 486-transportation by pipelines. Table 2 shows that the subsectors with the highest emissions are 327 (air), 313 (water) and 486 (soil). The first two subsectors represent traditional economic activities in the region, and the latter is the product of public policies applied for the treatment of domestic and industrial water. Air emissions, from activity 327 , consist mainly of $\mathrm{CO}_{2}$, chlorodifluoromethane and
Fig. 3 Percentage contribution of private consumption per substance
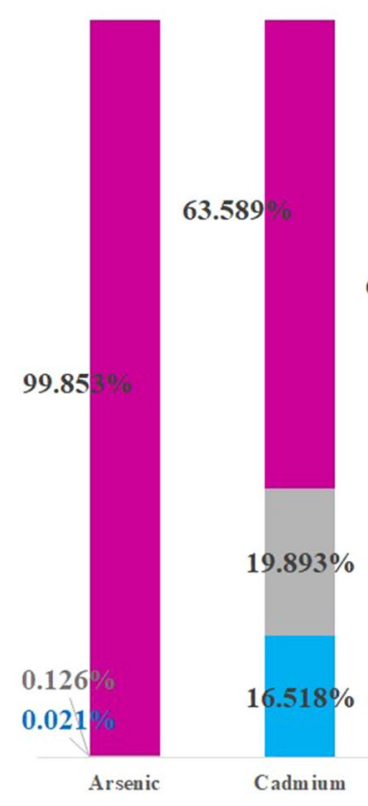
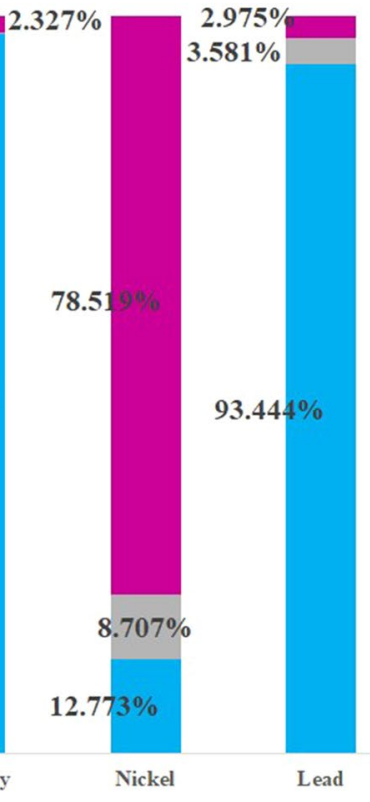
Fig. 4 Map of the location of the sources of benzene, cadmium, lead and carbon dioxide

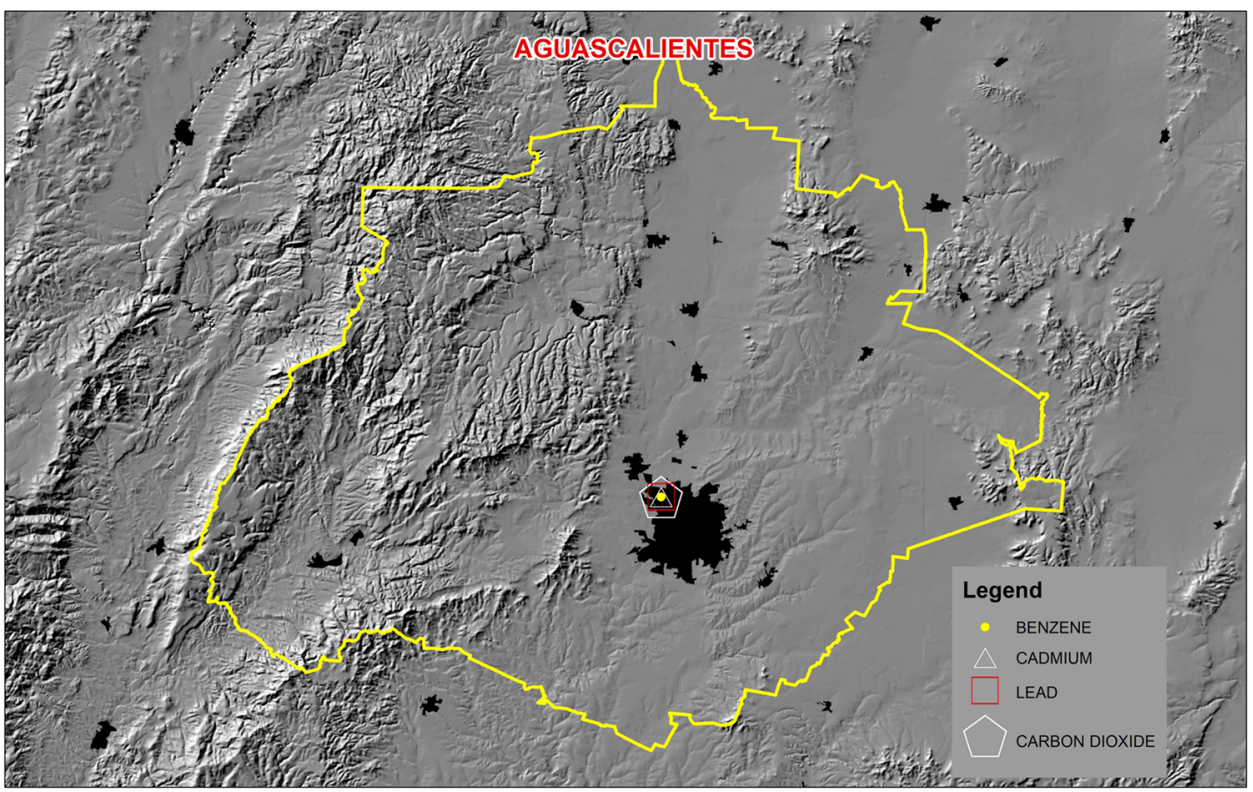

Fig. 5 Map of the location of the sources of nickel, mercury, nitrous oxide, arsenic and chrome

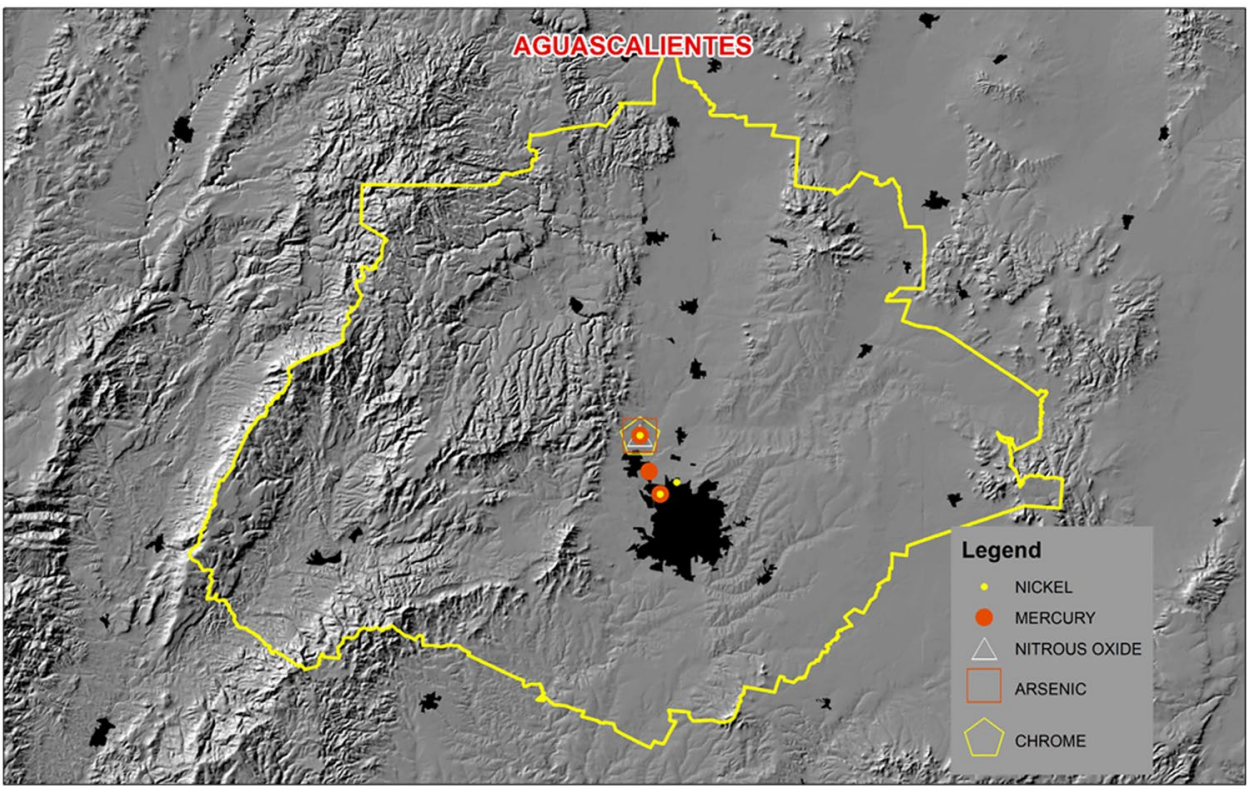

Table 2 Annual contribution of private consumption to emissions and transfer of pollutants by NAICS subsector [Tons]

\begin{tabular}{llll}
\hline NAICS subsector & Air & Water & Soil \\
\hline 311-Food industry & 0 & $2.26105 \mathrm{E}+14$ & $4.2565 \mathrm{E}+12$ \\
312-Beverage and tobacco industry & 0 & $7.77258 \mathrm{E}+11$ & 0 \\
313-Manufacture of textile inputs and textile finishing & 0 & $1.31095 \mathrm{E}+15$ & 0 \\
324-Manufacture of petroleum products and coal & $4.81029 \mathrm{E}+19$ & 0 & $8.46886 \mathrm{E}+13$ \\
327-Manufacture of products based on nonmetallic minerals & $1.06672 \mathrm{E}+22$ & $3.30124 \mathrm{E}+13$ & $9.19313 \mathrm{E}+12$ \\
331-Basic metal industries & $6.04334 \mathrm{E}+20$ & $2.14742 \mathrm{E}+13$ & $7.00707 \mathrm{E}+15$ \\
333-Manufacture of machinery and equipment & $3.66749 \mathrm{E}+21$ & 0 & 0 \\
339-Other manufacturing industries & $2.29658 \mathrm{E}+19$ & 0 & $9.73458 \mathrm{E}+16$ \\
486-Transportation by pipelines & $9.20033 \mathrm{E}+18$ & 0 & 0 \\
562-Waste and waste management and remediation services & $3.0119 \mathrm{E}+19$ & 0 & \\
\hline
\end{tabular}


Table 3 Percentage contribution by subsector of private consumption per substance in air (\%)

\begin{tabular}{|c|c|c|c|}
\hline Air & Arsenic (\%) & Cadmium (\%) & Chrome (\%) \\
\hline 324-Manufacture of petroleum products and coal & 0 & 0 & 0 \\
\hline 327-Manufacture of products based on nonmetallic minerals & 0.000000859079 & 0.000000157460 & 0.000010022249 \\
\hline 331-Basic metal industries & 0.000000534424 & 0.000000059380 & 0.001042942285 \\
\hline 333-Manufacture of machinery and equipment & 0.000000779380 & 0.000000111477 & 0.000000104850 \\
\hline 339-Other manufacturing industries & 0 & 0 & 0 \\
\hline 486-Transportation by pipelines & 0 & 0 & 0 \\
\hline 562-Waste and waste management and remediation services & 0 & 0 & 0 \\
\hline Air & Mercury (\%) & Nickel (\%) & Lead (\%) \\
\hline 324-Manufacture of petroleum products and coal. & 0 & 0 & 0 \\
\hline 327-Manufacture of products based on nonmetallic minerals. & 0.000001718085 & 0.000002892083 & 0.000005440664 \\
\hline 331-Basic metal industries. & 0.000000118761 & 0.000112959428 & 0.002435206362 \\
\hline 333-Manufacture of machinery and equipment. & 0.000000018535 & 0.000000190315 & 0.000000193704 \\
\hline 339-Other manufacturing industries. & 0 & 0 & 0 \\
\hline 486-Transportation by pipelines. & 0 & 0 & 0 \\
\hline 562-Waste and waste management and remediation services. & 0 & 0 & 0.01727999233 \\
\hline Air & Carbon dioxide (\%) & Benzene (\%) & Formaldehyde (\%) \\
\hline 324-Manufacture of petroleum products and coal. & 100 & 0 & 0 \\
\hline 327-Manufacture of products based on nonmetallic minerals. & 99.999978910159 & 0 & 0 \\
\hline 331-Basic metal industries. & 99.996403930889 & 0 & 0 \\
\hline 333-Manufacture of machinery and equipment. & 99.956487005063 & 0.00000931663 & 0.04339583606 \\
\hline 339-Other manufacturing industries. & 100 & 0 & 0 \\
\hline 486-Transportation by pipelines. & 99.998977481041 & 0.00055490721 & 0 \\
\hline 562-Waste and waste management and remediation services. & 99.982720007670 & 0 & 0 \\
\hline Air & Phenol (\%) & $\begin{array}{l}\text { Chlorodifluorometh- } \\
\text { ane (\%) }\end{array}$ & Acetaldehyde (\%) \\
\hline 324-Manufacture of petroleum products and coal. & 0 & 0 & 0 \\
\hline 327-Manufacture of products based on nonmetallic minerals. & 0 & 0 & 0 \\
\hline 331-Basic metal industries. & 0 & 0 & 0 \\
\hline 333-Manufacture of machinery and equipment. & 0.000004653506 & 0.000011185767 & 0 \\
\hline 339-Other manufacturing industries. & 0 & 0 & 0 \\
\hline 486-Transportation by pipelines. & 0 & 0 & 0.00046761175 \\
\hline 562-Waste and waste management and remediation services. & 0 & 0 & 0 \\
\hline Air & Furans (\%) & Dioxins (\%) & Methane (\%) \\
\hline 324-Manufacture of petroleum products and coal. & 0 & 0 & 0 \\
\hline 327-Manufacture of products based on nonmetallic minerals. & 0.000000000021 & 0.000000000201 & 0 \\
\hline 331-Basic metal industries. & 0 & 0 & 0.000004248470 \\
\hline 333-Manufacture of machinery and equipment. & 0 & 0 & 0 \\
\hline 339-Other manufacturing industries. & 0 & 0 & 0 \\
\hline 486-Transportation by pipelines. & 0 & 0 & 0 \\
\hline 562-Waste and waste management and remediation services. & 0 & 0 & 0 \\
\hline Air & Nitrous oxide (\%) & Total (\%) & \\
\hline 324-Manufacture of petroleum products and coal. & 0 & 100 & \\
\hline 327-Manufacture of products based on nonmetallic minerals. & 0 & 100 & \\
\hline 331-Basic metal industries. & 0 & 100 & \\
\hline 333-Manufacture of machinery and equipment. & 0.00009060472 & 100 & \\
\hline 339-Other manufacturing industries. & 0 & 100 & \\
\hline 486-Transportation by pipelines. & 0 & 100 & \\
\hline
\end{tabular}


Table 3 (continued)

\begin{tabular}{lll}
\hline Air & Nitrous oxide (\%) & Total (\%) \\
\hline $562-$ Waste and waste management and remediation services. & 0 & 100 \\
\hline
\end{tabular}

Table 4 Percentage contribution by subsector of private consumption per substance in water (\%)

\begin{tabular}{|c|c|c|c|c|}
\hline Water & Arsenic (\%) & Cadmium (\%) & Cyanide (\%) & Chrome (\%) \\
\hline 311-Food industry & 8.680 & 7.634 & 11.647 & 10.724 \\
\hline 312-Beverage and tobacco industry & 0.719 & 8.982 & 5.988 & 29.940 \\
\hline $\begin{array}{l}\text { 313-Manufacture of textile inputs and textile } \\
\text { finishing }\end{array}$ & 0 & 0 & 0 & 0 \\
\hline $\begin{array}{l}\text { 327-Manufacture of products based on non- } \\
\text { metallic minerals }\end{array}$ & 0 & 25 & 0 & 25 \\
\hline 331-Basic metal industries & 2 & 0 & 98 & 0 \\
\hline Water & Mercury (\%) & Nickel (\%) & Lead (\%) & Total (\%) \\
\hline 311-Food industry & 0.06 & 29.47 & 31.78 & 100 \\
\hline 312-Beverage and tobacco industry & 0.48 & 29.94 & 23.95 & 100 \\
\hline $\begin{array}{l}\text { 313-Manufacture of textile inputs and textile } \\
\text { finishing }\end{array}$ & 0 & 46.17 & 53.83 & 100 \\
\hline $\begin{array}{l}\text { 327-Manufacture of products based on non- } \\
\text { metallic minerals }\end{array}$ & 0 & 25 & 25 & 100 \\
\hline 331-Basic metal industries & 0 & 0 & 0 & 100 \\
\hline
\end{tabular}

Table 5 Percentage contribution by subsector of private consumption per substance in soil (\%)

\begin{tabular}{|c|c|c|c|c|}
\hline Soil & Arsenic (\%) & Cadmium (\%) & Cyanide (\%) & Chrome (\%) \\
\hline 311-Food industry & 3.77 & 0 & 18.87 & 56.60 \\
\hline 324-Manufacture of petroleum products and coal & 15.22 & 15.22 & 22.83 & 15.22 \\
\hline 327-Manufacture of products based on nonmetallic minerals & 2.29 & 2.29 & 2.68 & 2.29 \\
\hline 331-Basic metal industries & 84.91 & 0.78 & 3.12 & 1.17 \\
\hline 333-Manufacture of machinery and equipment & 2.70 & 0.90 & 0.79 & 2.20 \\
\hline 486-Transportation by pipelines & 100 & 0 & 0 & 0 \\
\hline Soil & Mercury (\%) & Nickel (\%) & Lead (\%) & Total (\%) \\
\hline 311-Food industry & 1.89 & 18.87 & 0 & 100 \\
\hline 324-Manufacture of petroleum products and coal & 1.07 & 15.22 & 15.22 & 100 \\
\hline 327-Manufacture of products based on nonmetallic minerals & 0 & 2.29 & 88.06 & 100 \\
\hline 331_Basic metal industries & 0 & 3.12 & 6.71 & 100 \\
\hline 333-Manufacture of machinery and equipment & 0 & 87.29 & 6.07 & 100 \\
\hline 486-Transportation by pipelines & 0 & 0 & 0 & 100 \\
\hline
\end{tabular}

chromium and traces of lead, phenol, nickel and mercury, among others (Table 3). Similarly for activity 313 , with emissions of lead and nickel to water (Table 4). Finally, activity 486 transfers arsenic to the soil (Table 5). NOTE: These substances are not all the toxic substances that are emitted but are the only ones that do not comply with the limits dictated by Mexican standards. Subsectors 327 and 331 are those that recorded emissions to all media. These activities are closely related to one of the most representative industries in the region in the last 20 years, the assembly of motor vehicles. Subsector 331 also emits methane. It should be noted that it is not always the substance with the highest tonnage that causes the most damage or is the most toxic. In the case of $\mathrm{CO}_{2}$, its contribution is to the increase in the greenhouse effect. See Figs. 4 and 5. 


\section{Analysis and discussion}

The subsector 327 is the one that most contaminates with carbon dioxide (99.99997891\%) and traces of chromium, nickel, lead, arsenic, cadmium, mercury, furans and dioxins. In water, Table 4, the subsector that most contaminates is 313 with $53.83 \%$ lead and $46.17 \%$ with nickel. And for soil, Table 5, subsector 486 with arsenic. From Table 5, the food industry emits mainly chromium (56.6\%), nickel (18.87\%) and cyanide (18.87\%) and transfers it through the soil. Lead $(88.1 \%)$ is the main pollutant from subsector 327 . The same case for nickel $(87.3 \%)$ and subsector 333 (manufacture of machinery and equipment) and arsenic for pipeline transport. Tables 6,7 and 8 are generated from private consumption and tax withholding due to household consumption according to income [27]. As it is observed, the last five deciles are those that consume the most and therefore contribute by more than an order of magnitude with respect to the first five deciles, to the generation of pollutants in water in subsector 313 . The extreme case is when only the tenth decile exceeds by an order of magnitude; its contribution in the emission and transfer of pollutants in air is 333, 331-basic metallic industries and 324-manufacture of petroleum products and coal and soil is 311 -food industry. In the case of the last two deciles of income, pollution is mainly in soil in the productive subsector 333 and in water in 312 . This would be linked to specific consumption habits of the region. One of the main industries in Aguascalientes is frozen and bagged foods. This industry takes care of its consumption and landfills in water and air, not in the soil. There is also a mining industry that contributes to the transfer of pollutants, mainly in soil and water. It is a reality in the difficulty of obtaining samples in soil and subsoil than in air. The other extreme case is when all income deciles of households except the first provide pollutants by more than an order of magnitude compared to decile I. Emissions are in air (562-waste and

Table 6 Contribution in tons of pollutant per decile of household income by NAICS subsector and mean of transmission (air) (Tons/year, 2013)

\begin{tabular}{|c|c|c|c|c|c|c|c|c|}
\hline \multirow{2}{*}{$\begin{array}{l}\text { Air } \\
\\
\text { Tons per } \\
\text { year } \\
(2013)\end{array}$} & \multicolumn{2}{|c|}{ NAICS code } & \multicolumn{2}{|c|}{$\begin{array}{l}\text { 327-Manufacture of products } \\
\text { based on nonmetallic minerals. }\end{array}$} & \multicolumn{2}{|c|}{$\begin{array}{l}\text { 333-Manufacture of } \\
\text { machinery and equip- } \\
\text { ment }\end{array}$} & \multirow{2}{*}{$\begin{array}{l}\begin{array}{l}331-\text { Basic } \\
\text { metal indus- } \\
\text { tries }\end{array} \\
1.783 \mathrm{E}+19\end{array}$} & \multirow[t]{2}{*}{$\begin{array}{l}324-\text { Manufacture of petroleum } \\
\text { products and coal. }\end{array}$} \\
\hline & D1 & & \multicolumn{2}{|c|}{$3.148 \mathrm{E}+20$} & \multicolumn{2}{|l|}{$1.082 \mathrm{E}+20$} & & \\
\hline & D2 & & \multicolumn{2}{|c|}{$4.35 \mathrm{E}+20$} & \multicolumn{2}{|l|}{$1.496 \mathrm{E}+20$} & $2.465 \mathrm{E}+19$ & $1.962 \mathrm{E}+18$ \\
\hline & D3 & & \multicolumn{2}{|c|}{$5.346 \mathrm{E}+20$} & \multicolumn{2}{|l|}{$1.838 \mathrm{E}+20$} & $3.028 \mathrm{E}+19$ & $2.411 \mathrm{E}+18$ \\
\hline & D4 & & \multicolumn{2}{|c|}{$6.279 \mathrm{E}+20$} & \multicolumn{2}{|l|}{$2.159 \mathrm{E}+20$} & $3.557 \mathrm{E}+19$ & $2.831 \mathrm{E}+18$ \\
\hline & D5 & & \multicolumn{2}{|c|}{$7.491 \mathrm{E}+20$} & \multicolumn{2}{|l|}{$2.576 \mathrm{E}+20$} & $4.244 \mathrm{E}+19$ & $3.378 \mathrm{E}+18$ \\
\hline & D6 & & \multicolumn{2}{|c|}{$8.655 \mathrm{E}+20$} & \multicolumn{2}{|l|}{$2.976 \mathrm{E}+20$} & $4.903 E+19$ & $3.903 \mathrm{E}+18$ \\
\hline & D7 & & \multicolumn{2}{|c|}{$1.032 \mathrm{E}+21$} & \multicolumn{2}{|l|}{$3.549 \mathrm{E}+20$} & $5.849 \mathrm{E}+19$ & $4.655 \mathrm{E}+18$ \\
\hline & D8 & & \multicolumn{2}{|c|}{$1.288 \mathrm{E}+21$} & \multicolumn{2}{|l|}{$4.429 \mathrm{E}+20$} & $7.298 \mathrm{E}+19$ & $5.809 \mathrm{E}+18$ \\
\hline & D9 & & \multicolumn{2}{|c|}{$1.675 \mathrm{E}+21$} & \multicolumn{2}{|l|}{$5.759 \mathrm{E}+20$} & $9.49 \mathrm{E}+19$ & $7.553 \mathrm{E}+18$ \\
\hline & D10 & & \multicolumn{2}{|c|}{$3.145 \mathrm{E}+21$} & \multicolumn{2}{|l|}{$1.081 \mathrm{E}+21$} & $1.782 \mathrm{E}+20$ & $1.418 \mathrm{E}+19$ \\
\hline \multicolumn{2}{|l|}{ Air } & \multicolumn{2}{|c|}{ NAICS ncode } & \multicolumn{2}{|c|}{$\begin{array}{l}562-\text { Waste and waste management } \\
\text { and remediation services }\end{array}$} & \multicolumn{2}{|c|}{$\begin{array}{l}\text { 339-Other manufactur- } \\
\text { ing industries }\end{array}$} & 486-Transportation by pipelines \\
\hline \multirow[t]{10}{*}{ Tons per $y$} & $\operatorname{ar}(2013)$ & D1 & & $8.888 \mathrm{E}+17$ & & 6.777E+1 & & $2.715 \mathrm{E}+17$ \\
\hline & & D2 & & $1.228 \mathrm{E}+18$ & & $9.366 \mathrm{E}+1$ & & $3.752 \mathrm{E}+17$ \\
\hline & & D3 & & $1.509 \mathrm{E}+18$ & & $1.151 \mathrm{E}+1$ & & $4.61 \mathrm{E}+17$ \\
\hline & & D4 & & $1.773 \mathrm{E}+18$ & & $1.352 \mathrm{E}+1$ & & $5.415 \mathrm{E}+17$ \\
\hline & & D5 & & $2.115 \mathrm{E}+18$ & & $1.613 \mathrm{E}+1$ & & $6.461 E+17$ \\
\hline & & D6 & & $2.444 \mathrm{E}+18$ & & $1.863 \mathrm{E}+1$ & & $7.465 \mathrm{E}+17$ \\
\hline & & D7 & & $2.915 E+18$ & & $2.223 \mathrm{E}+1$ & & $8.904 \mathrm{E}+17$ \\
\hline & & D8 & & $3.637 E+18$ & & $2.773 E+1$ & & $1.111 \mathrm{E}+18$ \\
\hline & & D9 & & $4.73 \mathrm{E}+18$ & & $3.606 \mathrm{E}+1$ & & $1.445 \mathrm{E}+18$ \\
\hline & & D10 & & $8.879 E+18$ & & $6.77 E+18$ & & $2.712 \mathrm{E}+18$ \\
\hline
\end{tabular}


Table 7 Contribution in tons of pollutant per decile of household income by NAICS subsector and means of transmission (water) (Tons/year, 2013)

\begin{tabular}{|c|c|c|c|c|}
\hline Water & NAICS code & $\begin{array}{l}\text { 313-Manufacture of textile } \\
\text { inputs and textile finishing. }\end{array}$ & 311—Food Industry. & $\begin{array}{l}\text { 327-Manufacture of products } \\
\text { based on nonmetallic minerals. }\end{array}$ \\
\hline \multirow[t]{10}{*}{ Tons per year (2013) } & D1 & $3.869 \mathrm{E}+13$ & $6.672 \mathrm{E}+12$ & $9.742 \mathrm{E}+11$ \\
\hline & D2 & $5.346 \mathrm{E}+13$ & $9.221 \mathrm{E}+12$ & $1.346 \mathrm{E}+12$ \\
\hline & D3 & $6.569 E+13$ & $1.133 \mathrm{E}+13$ & $1.654 \mathrm{E}+12$ \\
\hline & D4 & $7.716 \mathrm{E}+13$ & $1.331 E+13$ & $1.943 E+12$ \\
\hline & D5 & $9.206 \mathrm{E}+13$ & $1.588 \mathrm{E}+13$ & $2.318 \mathrm{E}+12$ \\
\hline & D6 & $1.064 \mathrm{E}+14$ & $1.835 \mathrm{E}+13$ & $2.679 E+12$ \\
\hline & D7 & $1.269 \mathrm{E}+14$ & $2.188 \mathrm{E}+13$ & $3.195 \mathrm{E}+12$ \\
\hline & D8 & $1.583 \mathrm{E}+14$ & $2.73 E+13$ & $3.987 \mathrm{E}+12$ \\
\hline & D9 & $2.059 E+14$ & $3.55 \mathrm{E}+13$ & $5.184 \mathrm{E}+12$ \\
\hline & D10 & $3.865 \mathrm{E}+14$ & $6.666 \mathrm{E}+13$ & $9.732 \mathrm{E}+12$ \\
\hline Water & & NAICS code & 331-Basic metal industries & $\begin{array}{l}312 \text { - Beverage and } \\
\text { tobacco industry }\end{array}$ \\
\hline \multirow[t]{10}{*}{ Tons per year (2013) } & & D1 & $6.34 \mathrm{E}+11$ & $2.29 E+10$ \\
\hline & & D2 & $8.76 \mathrm{E}+11$ & 3.17E+10 \\
\hline & & D3 & $1.08 \mathrm{E}+12$ & $3.90 \mathrm{E}+10$ \\
\hline & & D4 & $1.26 \mathrm{E}+12$ & $4.58 \mathrm{E}+10$ \\
\hline & & D5 & $1.51 \mathrm{E}+12$ & $5.46 \mathrm{E}+10$ \\
\hline & & D6 & $1.74 \mathrm{E}+12$ & $6.31 \mathrm{E}+10$ \\
\hline & & D7 & $2.08 \mathrm{E}+12$ & $7.52 E+10$ \\
\hline & & D8 & $2.59 \mathrm{E}+12$ & $9.39 \mathrm{E}+10$ \\
\hline & & D9 & $3.37 \mathrm{E}+12$ & $1.22 \mathrm{E}+11$ \\
\hline & & D10 & $6.33 E+12$ & $2.29 E+11$ \\
\hline
\end{tabular}

waste management and remediation services) and water (327). And when the same thing happens with respect to the first two deciles, the pollutants are both in air (339-other manufacturing industries), water (311 and 331) and in soil (327). This could lead us to think that there is a relationship between the levels of poverty, diseases and marginal areas with the sites where there are pollutants related to these economic subsectors. The last one is beyond the scope of the present work. From Table 9, looking at the changes between 2012 and 2013, the large increases in the contribution to pollutants per inhabitant of arsenic in air and soil, as well as cadmium, chromium and mercury in air, are obvious. The decrease in cadmium, mercury, nickel and lead in water stands out, similarly, mercury in soil and benzene, formaldehyde, chlorodifluoromethane and acetaldehyde in air. By incorporating costs, elasticities are obtained by subsector and groups of subsectors, since there is no finer breakdown of the CTADA. Of particular note are subsectors 322-Paper industry and 339. Subsequently, in air, subsectors 324, 325 (chemical industry). 326 (Plastic and rubber industry), 333, 334 (Manufacture of computer equipment, communication, measurement and other electronic equipment, components and accessories). 335
(Manufacture of accessories, electrical appliances and electric power generation equipment). 336 (Manufacture of transport equipment). Finally, on the soil, 313 and 322 (Paper industry). The elasticity associated with the subsector that most pollutes in air (327) is 0.1807702 , while in the case of water, it is subsector 313 with an elasticity of 0.0669902 . See Table 10 . The subsectors with elastic elasticities are 324, 333 and 339 in pollutants transferred in air, inelastic are 211 (air, water and soil), 312 (air), 337 (water and soil) and 486 (water and soil) and unitary elasticity are 313 (air). All others are relatively inelastic regardless of the means of transfer. Reviewing the historical data of the RETC [17], it is found that as of 2014, there is no arsenic record in air, having its maximum in 2013 and the minimum in 2012. The same for cadmium ( $\max$ 2013 , $\min 2009$ ). There is also no record of organic/inorganic cyanide in water and soil as of 2014. The maximum emission in water occurred in 2004 and the minimum in 2010. In the case of soil, the maximum was in 2013 and the minimum in 2006. The last record of mercury in air and water was in 2013 and on soil in 2015. The years with maximum emission are 2013, 2004, 2010 by mean of transfer, respectively. Analogously, the minimums correspond to the years 2009, 2011 and 2012. Analyzing 
Table 8 Contribution in tons of pollutant per decile of household income by NAICS subsector and means of transmission (soil) (Tons/year, 2013)

\begin{tabular}{|c|c|c|c|c|}
\hline Soil & NAICS code & $\begin{array}{l}\text { 486-Transportation by pipe- } \\
\text { lines by pipelines }\end{array}$ & $\begin{array}{l}\text {-Manufacture of machin- } \\
\text { nd equipment }\end{array}$ & $\begin{array}{l}\text { 327-Manufacture of products } \\
\text { based on nonmetallic minerals }\end{array}$ \\
\hline \multirow{10}{*}{$\begin{array}{l}\text { Tons per year } \\
(2013)\end{array}$} & D1 & $2.873 \mathrm{E}+15$ & $2.068 \mathrm{E}+14$ & $7.179 \mathrm{E}+12$ \\
\hline & D2 & $3.97 \mathrm{E}+15$ & $2.858 \mathrm{E}+14$ & $9.92 \mathrm{E}+12$ \\
\hline & D3 & $4.878 \mathrm{E}+15$ & $3.511 E+14$ & $1.219 \mathrm{E}+13$ \\
\hline & D4 & $5.73 E+15$ & $4.124 \mathrm{E}+14$ & $1.432 \mathrm{E}+13$ \\
\hline & D5 & $6.836 \mathrm{E}+15$ & $4.921 E+14$ & $1.708 \mathrm{E}+13$ \\
\hline & D6 & $7.898 \mathrm{E}+15$ & $5.685 E+14$ & $1.974 \mathrm{E}+13$ \\
\hline & D7 & $9.421 \mathrm{E}+15$ & $6.782 E+14$ & $2.354 \mathrm{E}+13$ \\
\hline & D8 & $1.176 \mathrm{E}+16$ & $8.462 E+14$ & $2.938 \mathrm{E}+13$ \\
\hline & D9 & $1.529 \mathrm{E}+16$ & $1.1 \mathrm{E}+15$ & $3.82 E+13$ \\
\hline & D10 & $2.87 \mathrm{E}+16$ & $2.066 \mathrm{E}+15$ & $7.172 \mathrm{E}+13$ \\
\hline Soil & NAICS code & $\begin{array}{l}\text { 324-Manufacture of petroleum } \\
\text { products and coal. }\end{array}$ & 331-Basic metal industrie & 311-Food Industry \\
\hline \multirow[t]{10}{*}{ Tons per year (2013) } & D1 & $2.499 \mathrm{E}+12$ & $2.713 \mathrm{E}+11$ & $1.256 \mathrm{E}+11$ \\
\hline & D2 & $3.454 \mathrm{E}+12$ & $3.749 \mathrm{E}+11$ & $1.736 \mathrm{E}+11$ \\
\hline & D3 & $4.244 \mathrm{E}+12$ & $4.607 \mathrm{E}+11$ & $2.133 \mathrm{E}+11$ \\
\hline & D4 & $4.985 \mathrm{E}+12$ & $5.411 E+11$ & $2.505 E+11$ \\
\hline & D5 & $5.947 \mathrm{E}+12$ & $6.456 \mathrm{E}+11$ & $2.989 E+11$ \\
\hline & D6 & $6.871 \mathrm{E}+12$ & $7.459 \mathrm{E}+11$ & $3.454 \mathrm{E}+11$ \\
\hline & D7 & $8.196 \mathrm{E}+12$ & $8.897 E+11$ & $4.12 \mathrm{E}+11$ \\
\hline & D8 & $1.023 E+13$ & $1.11 \mathrm{E}+12$ & $5.14 \mathrm{E}+11$ \\
\hline & D9 & $1.33 \mathrm{E}+13$ & $1.444 \mathrm{E}+12$ & $6.684 \mathrm{E}+11$ \\
\hline & D10 & $2.497 E+13$ & $2.71 \mathrm{E}+12$ & $1.255 \mathrm{E}+12$ \\
\hline
\end{tabular}

some of the emission sources, Pemex refining stopped producing acetaldehyde and two of the three companies that produced arsenic emissions in air stopped doing so. The third one does not appear in the RETC 2014. One of them also issued and transferred cyanide in soil.

From the breakdown of the SAMAgs13 in households, the results of Tables 6,7 and 8 were obtained, associating economic activities with household consumption by decile of income. And taking advantage of all the results presented, Tables 9 and 10 are generated. Together with information from the RETC, Figs. 4 and 5 are generated. The black pixels represent urban areas. As can be seen, the emitting sources can be located on the periphery of the largest urban zone and others small urban zones. In this area, the vehicle assembly, textile industry, frozen food industry and the water treatment plant are mainly located.

In the region of the present study, activities in the paper industry do not exceed the allowed limit of emissions $\mathrm{CO}_{2}$. Taking into account all activities in the region, the tons per capita of $\mathrm{CO}_{2}$ are 2.9161262 much lower than the case of China [20]. The annual increase is greater than $150 \%$ (Table 9). Regarding the emissions of other harmful substances reported in these activities, the impact is lower in the case of air with elasticity (tons of pollutants-remediation costs) of 0.002782 , while in soil, it is 0.8633319 (Table 10). In contrast to the work of Deschaine et al. [24], the region is mainly manufacturing (Tables 4, 5 and 6) and agriculture. The main source of water is underground. The exploitation of the aquifers (for the self-supplied industry: $18 \%$ surface, $82 \%$ underground) and its contamination is a problem that the authorities do not want to see. Water quality monitoring determines the largest urban area and its periphery as contaminated $[34,35]$. This indicates of the mobility of pollutants from soil and water to the subsoil. The water quality indicators do not specify the chemical composition. The treated water flow by industrial use is just $0.171 \mathrm{~m}^{3} / \mathrm{s}$. The aquifers in deficit condition in the region and the main water suppliers for consumptive use are the Aguascalientes Valley, Chicalote Valley, Llano, Venadero and Calvillo Valley. Renewable water per capita ( $\mathrm{m}^{3} / \mathrm{hab} /$ year) went from 1535 (2012) to 1515 (2013) and continues to decrease to 1419 (2017). These data correspond to the entire hydrological administrative region 
Table 9 Contribution of pollutants in tons per capita per year

\begin{tabular}{llll}
\hline Substance & Tons per capita 2012 & Tons per capita 2013 & Porcentage change \\
\hline Arsenic in-air & $8.15157 \mathrm{E}-11$ & $3.86684 \mathrm{E}-08$ & $47,336.7 \%$ \\
Arsenic in-water & $4.26551 \mathrm{E}-08$ & $6.90412 \mathrm{E}-08$ & $61.9 \%$ \\
Arsenic in-soil & $8.72711 \mathrm{E}-09$ & $1.45748 \mathrm{E}-07$ & $1,570.1 \%$ \\
Cadmium in-air & $1.57238 \mathrm{E}-10$ & $6.49456 \mathrm{E}-09$ & $4,030.4 \%$ \\
Cadmium in-water & $1.84335 \mathrm{E}-07$ & $6.80202 \mathrm{E}-08$ & $-63.1 \%$ \\
Cadmium in-soil & $2.45538 \mathrm{E}-08$ & $3.37948 \mathrm{E}-08$ & $37.6 \%$ \\
Cyanide in-water & $3.78034 \mathrm{E}-08$ & $9.76558 \mathrm{E}-08$ & $158.3 \%$ \\
Cyanide in-soil & $2.2747 \mathrm{E}-08$ & $3.3741 \mathrm{E}-08$ & $48.3 \%$ \\
Chrome in-air & $6.88001 \mathrm{E}-09$ & $8.80401 \mathrm{E}-07$ & $12,696.5 \%$ \\
Chrome in-water & $9.29635 \mathrm{E}-08$ & $1.05356 \mathrm{E}-07$ & $13.3 \%$ \\
Chrome in-soil & $7.1785 \mathrm{E}-08$ & $8.696 \mathrm{E}-08$ & $21.1 \%$ \\
Mercury in-air & $4.44819 \mathrm{E}-11$ & $4.88692 \mathrm{E}-08$ & $109,763.1 \%$ \\
Mercury in-water & $1.62762 \mathrm{E}-09$ & $7.92714 \mathrm{E}-10$ & $-51.3 \%$ \\
Mercury in-Soil & $1.42934 \mathrm{E}-09$ & $1.98884 \mathrm{E}-09$ & $39.1 \%$ \\
Nickel in-air & $3.99711 \mathrm{E}-08$ & $1.61866 \mathrm{E}-07$ & $305.0 \%$ \\
Nickel in-water & $3.81191 \mathrm{E}-07$ & $2.55791 \mathrm{E}-07$ & $-32.9 \%$ \\
Nickel in-soil & $2.9674 \mathrm{E}-07$ & $5.03858 \mathrm{E}-07$ & $69.8 \%$ \\
Lead in-air & $1.71125 \mathrm{E}-06$ & $1.82683 \mathrm{E}-06$ & $6.8 \%$ \\
Lead in-water & $4.70116 \mathrm{E}-07$ & $2.7072 \mathrm{E}-07$ & $-42.4 \%$ \\
Lead in-soil & $1.51736 \mathrm{E}-07$ & $2.67251 \mathrm{E}-07$ & $76.1 \%$ \\
Carbon dioxide in-air & 1.177430058 & 2.98161262 & $-53.2 \%$ \\
Benzene in-air & $3.64772 \mathrm{E}-07$ & $1.68346 \mathrm{E}-07$ & $-10.9 \%$ \\
Formaldehyde in-air & $7.24546 \mathrm{E}-06$ & $7.1782 \mathrm{E}-06$ & $-59.0 \%$ \\
Phenol in-air & $5.16197 \mathrm{E}-10$ & $7.69747 \mathrm{E}-10$ & \\
Chlorodifluoromethane & $2.25513 \mathrm{E}-07$ & $2.02033 \mathrm{E}-07$ & \\
$\quad$ (HCFC-22) in-air & $1.47788 \mathrm{E}-10$ & $6.06618 \mathrm{E}-11$ & \\
Acetaldehyde in-air & & & $-1 \%$ \\
\hline
\end{tabular}

Table 10 Elasticities of pollutants in air, water and soil by NAICS subsector

\begin{tabular}{|c|c|c|c|}
\hline Elasticities & Air & Water & Soil \\
\hline 112-Breeding and exploitation of animals & 0.0638734 & 0.0644641 & 0.4680686 \\
\hline 212-Mining of metallic and nonmetallic minerals, except oil and gas & 0.2913318 & 0.1450134 & 0.1585721 \\
\hline 222-Water supply and gas supply by pipelines to the final consumer & 0.0314354 & 0.001083 & 0.0827938 \\
\hline 236-Edification & 0.9817515 & 0.4354021 & 0.5722842 \\
\hline 311-Food industry & 0.2780693 & 0.0366766 & 0.0089656 \\
\hline 312-Beverage and tobacco industry & 0 & 0.045967 & 0.0648136 \\
\hline 313-Manufacture of textile inputs and textile finishing & 1 & 0.0669902 & 0.9382387 \\
\hline 315-Manufacture of clothing & 0.0788321 & 0.0789229 & 0.1462753 \\
\hline 321 -Wood industry & 0.1944613 & 0.0442105 & 0.0586031 \\
\hline 322-Paper industry & 0.002782 & 0.1952351 & 0.8633319 \\
\hline 324-Manufacture of petroleum products and coal & 1.9321801 & 0.2582712 & 0.1442176 \\
\hline 327-Manufacture of products based on nonmetallic minerals & 0.1807702 & 0.1022541 & 0.092903 \\
\hline 331_Basic metal industries & 0.7957451 & 0.1434723 & 0.0001002 \\
\hline 333-Manufacture of machinery and equipment & 1.1259778 & 0.0911974 & 0.6012279 \\
\hline 337-Manufacture of furniture, mattresses and blinds & 0.037986 & 0 & 0 \\
\hline 339-Other manufacturing industries & 1.446761 & 0.9752888 & 0.0384421 \\
\hline 486-Transportation by pipelines & 0.2821848 & 0 & 0 \\
\hline
\end{tabular}


that also includes other states. Observing Figs. 4 and 5, the location of the pollutant emitting sources is found in the Aguascalientes Valley, one of the areas with deficit in the water supply and with quality degree: contaminated. Comparing results with those of Bhalla and Deschaine [24], Bhalla et al. [25] and Expansion [36] for the years 2010, 2014 and 2017 are calculated: GDP per capita of Malaysia (6830€; 8411€; 8827€), Mexico (6990€; 8268€; $8317 €$ ) and Aguascalientes (5071€; 9350€; 10,772€).Taking into account the density (habitants $/ \mathrm{Km}^{2}$ ): Malaysia $(86 ; 93 ; 97)$, Mexico $(58 ; 65 ; 63)$ and Aguascalientes $(211$; $230 ; 231)$. Aguascalientes is above the national average in both GDP per capita and density, which places it as a region where people from other regions arrive. This great change is reflected from 2010 to 2014 after the assembly companies of motor vehicles settled. From 2014 to 2017, the migratory flows stabilize causing the increase in water stress in the region. With the increase in population, infrastructure and services are required. Consumption is increased in the region, while Mexico decreases its density from 2014 to 2017 and growing GDP per capita very little. As noted, the increase in GDP per capita is directly reflected in density. It is necessary to take into account both the productive part and the intermediate and final consumption, disposition of natural resources, socio-demographic indicators, among others, in order to quantify the impacts of human activities. From the above, the need to implement public policies that take into account the valuation of economic development with the exploitation of natural resources, the degradation and depletion of the environment is noted. Fauzi A. et al. [37] raise this fact for a large conservation area. Their reasoning can be adapted to the region of the present study from the point of view of surface and underground water disposition for consumptive use, as well as the degradation of the environment by the emission and transfer of harmful substances. As an aspect important in the present study is the contamination in the three transfer media, works on rivers and their tributaries, such as those of Wu and Xia [38], demonstrate the importance of relating water quality to soil chemical composition, deposits of these in the flow, climatic records of temperature and precipitation. This type of models requires the nesting of other sub-models as inputs and extends them to underground flows. An important aspect is that automotive vehicle assembly companies are foreign, largely transferring $\mathrm{CO}_{2}$ emissions (and other substances) to the region through international trade (mainly with the US). As is the case in Austria [26], where for each unit of final domestic demand corresponds to $1 / 3$ of domestic $\mathrm{CO}_{2}$ emissions and $2 / 3$ outside its borders. For Aguascalientes State, it is $52.6 \%$ domestic and $47.4 \%$ outside.

\section{Conclusions}

The objectives met the relationship between economic structure and polluting emissions through private consumption; in particular, the tons of pollutant emissions per capita were found, which is one of the indicators of the SDGs. An important achievement is that this indicator is available for substances other than $\mathrm{CO}_{2}$ as well as the economic activity from which it comes. The maps of the main emissions show the impact of human activities on pollutant emissions, since the highest emissions are found in urban areas, in the industrial zone mainly. The results show the impact on the consumption habits of the population and their relationship with the main industries in the region. The largest elasticities do not correspond to the most polluting subsectors, just as the most harmful pollutants do not correspond to the most abundant or massive ones.

The methodology used is robust and replicable to other regions, but it suffers in its dependence on available data. It can be complemented with other methodologies and cover other interesting aspects such as well-being, poverty, diseases, among others.

Finally, by extending the study to other pollutants in addition to greenhouse gases, as well as their differentiation by means of transfer, it broadens the perspective of ecological damage.

\section{Compliance with ethical standards}

Conflict of interest The authors declare that they have no conflict of interest.

\section{References}

1. Alcántara V (2007) Análisis input-output y emisiones de $\mathrm{CO}_{2}$ en España: un primer anílisis para la determinación de sectores clave en la emisión, Facultat de Ciéncies Económiques i Empresarials, Universitat Autónoma de Barcelona, Spain, July, available at: https://www.researchgate.net/publication/24138233_Anali sis_Input-Output_Y_Emisiones_De_Co2_En_Espana_Un_Prime r_Analisis_Para_La_Determinacion_De_Sectores_Clave_En_La_ Emision. Accessed 1 Jan 2019

2. González D (2012) La industria mexicana y su intensidad de carbón. Revista Digital Universitaria 13(8):1-11

3. Vera M.E. Domínguez (2009) Aplicación de un modelo de multiplicadores contables y análisis estructural a políticas sociales seleccionadas en el estado de Nuevo León, Ensayos, volumen XXVIII, No. 2, November, pp. 95-137, ISSN 2448-8402. available at: http://ensayos.uanl.mx/index.php/ensayos/article/ view/92. Accessed 5 may 2018

4. Pyatt G, Round Jl (1979) Accounting and fixed price multipliers in a social accounting matrix framework. Econ $J$ 89(356):850-873 
5. Jacques Defourny J, Thorbecke E (1984) Structural path analysis and multiplier decomposition within a social accounting matrix. Econ J 94(373):111-136

6. Ayala Gaytán EA, Chapa Cantú JC (2019) Demanda agregada y desigualdad regional por género en México. Cuadernos de Economía 38(77):399-424

7. Moreno Ruíz LB, Anguiano Mondragón E (2006) Regionalización de la matriz insumo-producto del Distrito Federal mediante coeficientes de localización, Tiempo Económico, volume 2 No. 4 pp 5-20, available at: https://biblat.unam.mx/es/revista/ tiempo-economico/articulo/regionalizacion-de-la-matriz-insum o-producto-del-distrito-federal-mediante-coeficientes-de-local izacionhttp://tiempoeconomico.azc.uam.mx/wp-content/uploa ds/2017/07/04te1.pdf. ISSN 1870-1434. Accessed 20 May 2018

8. Ayala-Gaytán EA, Cantú-Chapa J (2013) Economic impact of frost and financing of replanting in Sinaloa. Revista de Economía No 81, July-December, pp 11-55. available at: http://www.revis ta.economia.uady.mx/2013/XXX/81/1.pdf. Accessed 24 Dec 2018

9. Torre Cepeda LE, Alvarado Ruíz JA, Quiroga Treviño M (2017) “Matrices Insumo-Producto Regionales: Una Aplicación al Sector Automotriz en México. working paper N 2017-12, Banco de México, Documento de investigación, Mexico, July, available at: http://www.banxico.org.mx/publications-and-press/banco -de-mexico-working-papers/\%7B999B04F8-F5D5-F453-17DC7A20735D6CE8\%7D.pdf. Accessed 19 Feb 2018

10. Bravo Pérez HM, Castro Ramírez JC (2006) Construcción de una matriz de contabilidad social con agua para el estado de Guanajuato. CIDE No 176. http://libreriacide.com/librospdf/DTAP-176. pdf

11. Rodríuez Oreggia y Román E (1995) Construcción de una matriz de contabilidad social para el estado de Nuevo León. Maestría thesis, Universidad Autónoma de Nuevo León. http://eprin ts.uanl.mx/7620/

12. Ooster J, Stelder D (2008) Syllabus regional and interregional IO analysis, working paper, faculty of economics and business, University of Groningen, The Netherlands, October, available at: xxxxx (Accessed 17 August 2017). available at: https://www. researchgate.net/publication/242180361_Syllabus_Regional_ and_Interregional_IO_Analysis. Accessed 15 Sept 2018

13. Flegg AT, Tohmo T (2013) Regional input-output tables and the FLQ formula: a case study of Finland. Reg Stud 47(5):703-721

14. Martana K, Evison D, Lennox J, Manley B (2012) Constructing a regional social accounting matrix using non survey method for CGE Modeling; Paper presented at the 2012 (NZARES) Conference Tahuna Conference Centre-Nelson, New Zealand. August 30-31, available at: https://www.researchgate.net/publicatio n/259117269_Constructing_a_regional_Social_Accounting Matrix_using_non_survey_method_for_CGE_Modeling. Accessed 5 Feb 2019

15. Ruíz Nápoles $\mathbf{P}$ (2011) Estimación de los costos relativos de las emisiones de gases de efecto invernadero en las ramas de la economía mexicana. El Trimestre Económico Volume LXXVIII (1), No 309, Jan-Mar, pp 173-191. available at: https://www. academia.edu/23458893/Estimaci\%C3\%B3n_De_Los_Costo s_Relativos_De_Las_Emisiones_De_Gases_De_Efecto_Inver nadero_en_Las_Ramas_De_La_Econom\%C3\%ADa_Mexicana_. Accessed 3 May 2016

16. INEGI (2012) Sistema de Cuentas Nacionales de México. Cuentas económicas y ecológicas de México, 2006-2010, Instituto Nacional de Estadística y Geografía, Aguascalientes, México, ISBN 978-607-494-279-8. Available at: https://www.inegi.org. mx/temas/ee/default.html\#Publicaciones. Accessed 2 Feb 2017

17. SEMARNAT (2016) Compendio de Estadística Ambientales; Registro de emisiones de transferencia de contaminantes. available at: https://www.gob.mx/semarnat/acciones-y-programas/siste ma-nacional-de-informacion-ambiental-y-de-recursos-natur ales. Accessed 1 August 2018

18. Livas-García A (2015) Análisis de insumo-producto de energía y observaciones sobre el desarrollo sustentable, caso mexicano 1970-2010; Ingeniería, Investigación y Tecnología, XVI(2), pp 239-251. http://www.scielo.org.mx/scielo.php?script=sci arttext\%26pid=S1405-77432015000200008 ISSN 1405-7743. Accessed 13 Mar 2020

19. Vázquez A (1995) A note on the arc elasticity of demand. Estudios Econ 10(2):1. https://doi.org/10.24201/ee.v10i2.264

20. Yue W, Cai Y, Rong Q, Cao L, Wang X (2014) A hybrid MCDA-LCA approach for assessing carbon foot-prints and environmental impacts of China's paper producing industry and printing services. Environ Syst Res 3:4

21. Alghwail ADA (2019) Environmental ethics of water resources management. China USA Bus Rev 18(1):44-49. https://doi. org/10.17265/1537-1514/2019.01.004

22. Gijón-Cruz AS, Espinosa-Rojas CR, Reyes-Morales RG (2018) Analysis of subsistence and well-being strategies through amodel of household economics in the Tlacolula Valley ofOaxaca State Mexico. China USA Bus Rev 17(5):221-233. https://doi. org/10.17265/1537-1514/2018.05.001

23. Ledesma-Carrión DE, Hernández-Hernández L (2017) Is the poverty of the country a consequence of the structure of the Mexican economy? Int J Acc Res 5:2. https://doi.org/10.4172/2472$114 X .1000163$

24. Deschaine LM, Lillys TP, Pintér JD (2013) Groundwater remediation design usingphysics-based flow, transport, and optimization technologies. Environ Syst Res 2:6

25. Bhalla S, Baharuddin Z, Al-Amin AQ, Kamal N, Che Z (2017) Bioeconomy malaysia report. Economic findings report. The vision for 2020 and beyond; Malaysian Biotechnology Corporation (BiotechCorp) and Frontier Private Advisors Sdn. Bhd. http://www.bioeconomycorporation.my/wp-content/uploa ds/2017/08/151204_Bioeconomy_Economics_Report_for_print ing.pdf

26. Bednar-Friedl $B$, Jaramillo $P$ Muñoz, Schinko $T$, Steininger $K$ (2010) The carbon content of Austrian trade flowsin the European and international tradecontext. FIW Research Reports 2009/10 Num. 05,FIW a collaboration of WIFO (www.wifo.ac.at), WIIW (www.wiiw.ac.at) and WSR (www.wsr.ac.at)

27. SHCP (2012) Distribución del pago de impuestos y recepción del gasto público y por deciles de hogares y personas. Resultados para el año 2012; January 2015. https://www.gob.mx/ shcp/documentos/distribucion-del-pago-de-impuestos-yrecepcion-del-gasto-publico-por-deciles-de-hogares-y-perso nas-para-el-ano-2012-presentado-en-2015https://www.gob. $\mathrm{mx} / \mathrm{shcp} /$ documentos/distribucion-del-pago-de-impuestosy-recepcion-del-gasto-publico-por-deciles-de-hogares-y-perso nas-para-el-ano-2014-presentado-en-2016. Accessed 17 March 2018

28. Allen RGD, Lerner AP (1934) The concept of arc elasticity of demand. Rev Econ Stud 1(3):226-230

29. Velázquez E (2006) An input-output model of water consumption: analysing intersectorial water relationships in Andalusia. Ecol Econ 56:226-240

30. Miller RE, Blair PD (2009) Input-output analysis foundations and extensions. Cambridge Universitu Press, United Kingdom

31. INEGI (2015) Anuario Estadístico y Geográfico de Aguascalientes. Instituto Nacional de Estadística y Geografía, Aguascalientes, Mexico, ISBN 978-607-494-779-3. Available at: http://www.diput ados.gob.mx/sedia/biblio/usieg/Anuarios_2016/Aguascalie ntes/referencias_generales.pdf. Accessed 3 Oct 2018

32. López-Cobo M (2016) Regionalisation of Social Accounting Matrices for the EU-28 in 2010, Technical report by the Joint Research Centre (JRC), the European Commission's science 
and knowledge service, Publications Office of the European Union, ISBN 978-92-79-64460-3, ISSN 1831-9424. https://doi. org/10.2791/1337

33. Ángel JP, García D, Maldonado N (2017) Revisión de metodologías para la construcción de matrices de contabilidad social regionales (MCSR), Ensayos de Economía, Universidad Autónoma de Nuevo León, no 51, July-Dec, pp 125-149, available:https://revistas.unal.edu.co/index.php/ede/article/ view/69117. Accessed 12 Dec 2018

34. CONAGUA (2013) Atlas del Agua en México 2013. Secretaría de Medio Ambiente y Recursos Naturales. http://www.conag ua.gob.mx/SINA

35. CONAGUA (2015) Estadísticas del Agua en México, edición 2015. Secretaría de Medio Ambiente y Recursos Naturales pp 248. http://www.conagua.gob.mx/SINA
36. Expansión 20 february 2020 available. https://datosmacro.expan sion.com/

37. Fauzi A, Erlinda N, Sutomo S, Putri KEl (2016) Assessment of sustainable regional development policies: a case study of Jambi province, Indonesia. Econ World 4(5):224-237. https://doi. org/10.17265/2328-7144/2016.05.003

38. Wu Q, Xia X (2014) Trends of water quantity and water quality of the Yellow River from 1956 to 2009: implications for the effect of climate change. Environ Syst Res 3:1

Publisher's Note Springer Nature remains neutral with regard to jurisdictional claims in published maps and institutional affiliations. 